\section{ASTRONOMICAL PHENOMENA FOR THE WEEK, I885, MARCH 29 TO APRIL 4}

(FOR the reckoning of time the civil day, commencing at Greenwich mean midnight, counting the hours on to 24 , is here employed.)

\section{At Greenwich on March 29}

Sun rises, $5^{\text {h. }} 44 \mathrm{~m}$.; souths, I2h. $4 \mathrm{~m} .44^{\circ} 7 \mathrm{~s}$.; sets, $18 \mathrm{~h} .27 \mathrm{~m}$.; decl. on meridian, $3^{\circ} 34^{\prime}$ N. : Sidereal Time at Sunset, $6 \mathrm{~h} .56 \mathrm{~m}$.

Moon (Full on March 30) rises, 17 h. 20m. ; souths, 23 h. 32m. ; sets, $5 \mathrm{~h} .33 \mathrm{~m} .^{*}$; decl. on meridian, $0^{\circ} 35^{\prime} \mathrm{S}$.

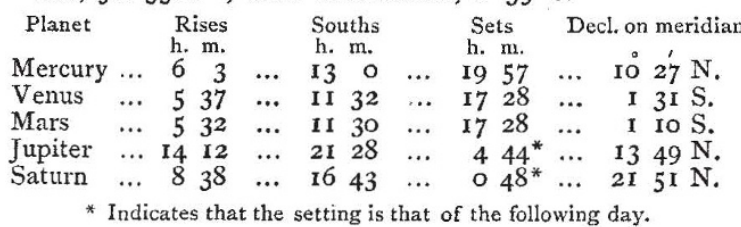

Occultations of Stars by the Moon

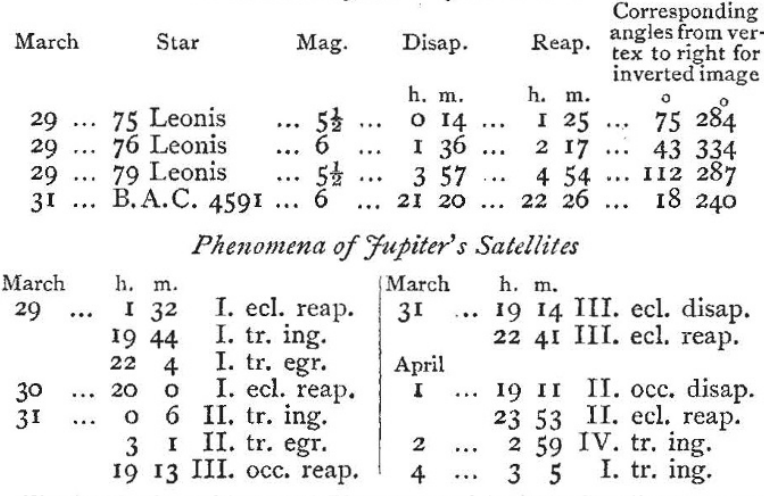

The Occultations of Stars and Phenomena of Jupiter's Satellites are such as are visible at Greenwich.

March 30.-Partial eclipse of the Moon. The times of first contact with the penumbra and shadow are $13 \mathrm{~h} .49 \mathrm{~m}$. and I $4 \mathrm{~h} .58 \mathrm{~m}$. respectively ; the middle of the eclipse is at $16 \mathrm{~h} .34 \mathrm{~m}$. ; the times of last contact with the shadow and penumbra are $18 \mathrm{~h} .9 \mathrm{~m}$. and $19 \mathrm{~h} .18 \mathrm{~m}$. respectively. The Moon will rise at Greenwich after having left the shadow but whilst still obscured by the penumbra.

\section{GEOGRAPHICAL NOTES}

Ir seems probable that the Geographical Societies of Berlin and Munich will join that of Vienna in sending Dr. Lenz to Africa.

Mr, O'Nelll, our Consul at Mozambique, who has done some excellent exploring work in the Lake Nyassa region, has just arrived in this country, and will shortly read a paper before the Royal Geographical Society.

AT the meeting of the Geographical Society on Monday, when a paper by Major Holdich was read on the geographical work of the Afghan Frontier Commission, Sir Richard Temple spoke in strong terms of the complete ignorance of geography in this country and the consequent incompetency of the public to judge of the true bearings of such a matter as that now pending between Russia and England. The Society, he remarked, performs a public service in bringing before the public such papers as that of Mr. Holdich, and we hope they will succeed in obtaining for geography the position it ought to have in English education.

We learn from the Times Paris Correspondent that the War Ministries of France, Germany, and Italy have recently been examining attentively geographical maps in relief, constructed on a system of which M. de Mendouca, a Portuguese Councillor of State, President of the Banco Lusitano, possesses the patent, and is the promulgator. These relief maps are stated to combine the advantages generally admitted to be possessed by relief maps and the convenience and accuracy of maps on flat surfaces. The Correspondent states that this new method rapidly reprodtices, by a cnemical and mechanical process, plane maps with the curves and altitudes in relief, so represented as to correspond absolutely with the elevations established by accurate observations. These maps are drawn on paper, which may be described as thin. They are not, however, put out of shape even by being trodden upon. Yet they may be rolled up and placed in the narrowest case, so that they are very portable and light. They are not injured by water. The Correspondent soaked one of them for forty-eight hours in water, and, on taking it out, all the part which was in relief-that is all the part subjected to chemical processes-remained absolutely intact. The relief, the Correspondent states, is produced on them in such a manner that at a single glance one can take in the whole topography of a district, its defiles and heights, its water-courses, and all the lesser obstacles of the country in which military operations have to be carried on. Of course relief maps are well known and plentiful. The drawback to those which include large areas is that the altitudinal scale has to be greatly exaggerated. Both in Germany and Switzerland beautiful reliefs of limited areas are made, not only in plaster, but also in papier-mâché, the horizontal and altitudinal scales of which are the same. These new maps, however, seem to possess many advantages over either plaster or papier-mâché, and we should like to know how large are the areas which are contained in them. We are also curious to learn the chemical process used, and whether embossing is not to some extent employed.

IN the Mittheilungen of the Vienna Geographical Society for February (Bd. xxviii. No, 2), Prof. Blumentritt describes the states existing in the Philippine Islands at the time of the Spanish Conquest. These were of two kinds : Mohammedan principalities, which were the larger and more important, the polity of which was based on the feudal system; and a vast number of small states, consisting of only a few villages each, in which the Government was based on a complicated system of slavery. The latter is described at considerable length, and is exceedingly interesting. Herr Heller completes his paper on the Rilo-Dagh; while Baron Kaulbars translates from the Russian the recent letters of Col. Prjevalsky from Central Asia. The President, we are glad to observe, was able to announce that the recent appeal of the Council for more members to enable the Society to take a place worthy of the Austrian capital in geographical science has been very successful, 402 new members having joined up to February 24. At the meeting held on that date the Librarian, Dr. Le Monnier, described Mr. Thomson's recent journey into Eastern equatorial Africa ; and Dr. Zehden read a paper on Shamanism in Upper Austria, which will be printed in the next part of the Transactions.

The last number of the China Review contains a lengthy paper on Formosa by Messrs. Colquhoun and Stewart-Lockhart. It professes to be based on all available sources of information, and on the evidence of those whu have resided and travelled in the island. The most interesting section is one on the Dutch in Formosa, which is followed by an account of the Chinese rule. The physical geography, and the cities and communications, a.e treated in some detail ; but the portion on the aborigines was written without much reference to "available sources." The precise position of these aborigines is one of the most curious problems in ethnology, and very much more has been written about them than the authors of this paper seem to be aware of. They note a very curious custom among the males. They are deprived of their eye-teeth, which are knocked out when they are quite young. By some it is thought that this improves the wind for hunting, whilst others consider that it increases the beauty of their appearance.

\section{ACCIDENTAL EXPLOSTONS PRODUCED BY} NON-EXPLOSIVE LIQUIDS ${ }^{1}$

\section{II.}

THE disaster on board the Triumph, combined with the fact that this xerotine siccative had been issued to H.M.'s ships generally, the authorities and officers of the navy having been in ignorance as to its dangerous nature, re-directed official attention

${ }^{2}$ Address delivered at the Royal Institution of Great Britain, Friday March $x_{3}$, I885, by Sir Frederick Abel, C.B., D.C.L., F.R.S., M.R.I. Continued from p. 472 . 
to the loss of the Doterel on April 26, 1881, while at anchor off Sandy Point, by an explosion, or rather by two distinct explosions following each other in very rapid succession, which caused the death of eight officers and I35 men, there being only twelve survivors of the crew. The inquiry by court-martial into the catastrophe had led to the conclusion that the primary cause of the destruction of that vessel was an explosion of gas in the coal-bunkers, caused by disengagement of fire-damp from the coal with which these were in part filled. Its distribution through the air in the bunkers and in air-spaces adjoining the ship's magazine was believed to have taken place to such an extent as to produce a violently explosive mixture, and that this had become accidentally inflamed, causing a destructive explosion, which was followed within half a minute by the much more violent explosion of the ship's magazine, containing four or five tons of powder, to which the flame from the exploding gas-mixture had penetrated.

The circumstances elicited by the inquiry, coupled with the information relating to explosions known to have occurred in coal-laden ships which had been collected by a Royal Commission in 1876 (of which the lecturer was a member), combined to lend a considerable amount of probability to the view adopted by the court-martial in explanation of an accident for which there appeared to be no other reasonable mode of accounting.

The conclusion arrived at led to the appointment of a committee under the presidency of Admiral Iuard (of which Prof. Warington Smyth and the lccturer were members) to inquire into the probabilities of coal-gas being evolved, and of an explosive gas-mixture accumulating in conscquence in the coalbunkers of ships of war, and into the possible extent and nature of damage which might be inflicted upon ships of war by ex plosions due to the ignition of such accumulations. The committee were also instructed, in the event of their finding that H.M.'s ships were liable to exposure to danger from such causes, to consider and devise the means best suited for preventing dangerous accumulations of gas in the coal-bunkers which aro distributed over the various parts of the ship in the different classes of vessels composing the Royal Navy.

The committec instituted a very careful inquiry, and a series of experimental investigations, including the firing of explosive gas-mixtures, in large wrought-iron tanks in the first instance, and afterwards in one of the large bunkers, empty of coal, in an old $\mathrm{m}$ an-of-war, which afforded some comparison with the condition, as regards the relative strength or powers of resistance of the surroundings, and with the position, relatively to the ship's magazine, of the particular bunker in the Doterel in which it was thought the explosion night have originated. The results of these expcriments could not be said to do more than lend some amount of support to the helief that effects of the nature of those ascribed to the first explosion in the 1)o:erel might have been produced by the ignition of a powerfully cxplosive gas-mixture, contained in the middle- or a thwart-ship's bunker of the ship. The committee's experimental investigations for ascertaining the best general method of securing the efficient ventilation of the coal-hunkers in different classes of men-of war wats, however, of considerable advalutage in learling to the general adoption of arrangements in II. M.'s ships whereby the possiblo accumulation in the bunkers of gas which may be liable to be occluded from coal after its introduction into them is effectually prevented, and the occurrence of the kind of accidents guarded against, of which there are several on record, due to the irnition of explosive mixtures which have been produced in coal-bunkers.

Although the inquiry instituted by the conrt-martial in August, 1881, into the loss of the Doterel was apparently very exhaustive, some :ignificant facts connected with the existence of a supply of xerotine siccative in the ship, which appear to have had a direct bearing upon the occurrence of the disaster, only came to light accidentally in January, 1832 . A caulker formerly on the Dutere', but then employed in the Iutus, recognised, while some painting was being done in that ship, at peculiar odour (as he called it, "the old smell") which he had noticed in the lower part of the Doterel the night before the explosion ; on inquiry as to the matcrial which gave rise to it, he learned that it was due to some of the same material, xerotine siccative, that had caused the explosion in the 7rizmth. Upon this being communicated to the authorities, an official inquiry was directed to be held, and. it was then elicited that the very offensive smell due to the crude petroleum spirit of which this xerotine siccative mainly consisted, had been observed not only by this man (who in his evidence before the court-martial had not alluded to the circumstance), but also by several others in the Doterel, betwcen decks, the night before the explosion; that, on the following day, a search was made for the cause of the odour, and that a jar containing originally about a gallon of the fluid, which was kept in a space at the bottom of the foremast, together with heavy stores of various kinds, was found to have been cracked, the principal portion of its contents having leaked out into the bottom of the ship. The cracked jar was handed up to the lower deck with the siccative still leaking from it, and orders were given to throw it overboard on account of the bad smell which it emitted; this was done within a very few minutes after the jar had been removed, and the first explosion occurred almost directly afterwards. Instructions had been given to clear up the leakage from the jar after the hatch of the mast-hole had been left off a litule time, and it appeared that a naked candle had been given to the man who handed the jar up out of the small store-hold described by that name. There appears very little room for cloubt that an explosive mixture of the vapour and air had not only been formed in the particular space where the jar was kept, but that it had also extended through the air-spaces at the bottom of the ship towards and underneath the powdermagazinc, so that even the air in the latter may have been in an explosive condition, as many hours had elapsed between the time when the smell of the petroleum spirit-vapour was first noticed and when the first explosion occurred.

The special committee which had inquired into the possibility of the occurrence of a violent gas explosion in the coal-bunkers of the Doterel was directed to institute experiments with a view of ascertaining whether the vapour evolved by this xerotine siccative woukd, in the circumstances indicated by the official inquiry, have furnished an explosive gas-mixture possessing sufficient power to have produced the effects resulting from the first explosion on the Doterel, and to have exploded the powtermagazine. A preliminary experiment showed that when a small quantity of the liquid was spilled at one extremity of a wooden channel 7 feet long and 2.5 inches by 3 inches in section, the vapour had diffused itsclf in the space of three minutes throughout the channel to such an extent that, on a light being applied at one end, the flame travelled along very rapidly to the other end, igniting a heap of gunpowder which had been placed there. Some of the liquit was also spilled upon the bottom of a very large sheet-iron tank, and aftcr this had remained closed for about twenty-four hours, being exposed on all sides to the cool air of an autumn night, and therefore not under conditions ncarly so favourable to evaporation as those obtaining in the hold of a ship, the application of flame produced an explosion of such violence as to tear open the tank. Experiments were also made with the liquid in an old man-of-war, under conditions somewhat similar to those which existed in the Doterd, and destructive effects were obtained of a nature to warrant the conclusion that the first explosion in the Doterel might have bcen due to the ignition of an explosive mixture of the air in the confined space at the bottom of the ship, with spirit vapour furnished by the liculud which had leaked out of the jar.

It is very instructive, as inclicating the manner in which volatile liquids of this class may, if their nature be unsuspected. To the causes of grave disasters, 10 mote that, while stringent regulations apply, and are sirictly enforced, in our nen-of-war in conncetion with the storage and treatment of explosives and inflammable bodies carried in the ship, the introduction into the service of this highly volatile liquid, and its supply to ships in small quantities, was specdily followed by two most calamitons accifints because the material was only lnown under the disguise of a name affording no indication of its character. Its danserous nature had consequently cscaped detection by the officials through whose hands it had passed, the makers of the prepara tion having, in a reprchensible manner which canuot but be stigmatised as criminal, withlheld the information which most probably would have, at the outset, acted as a prohibition to the adoption of this material loy the Admiralty for use in ships, or which would, at any rate, have led to the adoption of very special precautions in dealing with this material.

Although not initiated, nor attended, by any explosion, the accident which in Dccember, 1875 , caused the loss, by fire, of the training-ship Golinth off Grays (near Gravesend) and the death of several of the boys by drowning, claims notice as an illustration of the facility with which, by heedlessness, or inattention to obvious precautions, accidents may be brought about in the use as an illuminating agent of mineral oil or petroleum, even where these are of such low volatility, or high "flashing 
point," as to entitle them to be considered as safe, under all ordinary conditions, as vegetable or animal oils. 'The evidence elicited at the coroner's inquest showed that one of the boys of the Goliath, whose duty it was, at the time, to trim the lamps used in the ship, to place them in position and remove and extinguish them in the morning, and to whom this work had been but recently allotted, let fall a lamp which, after having lowered the flame, he had carried from its assigned position into the lamp- or trimming-room, and which he could hold no longer on account of its heated state. The heated oil was scattered upon the floor, and was apparently at once inflamed by the burning wick of the lamp; the floor of the room was, it appears, much impregnated with oil which had been let drop from time to time by lads employed upon the work of lamp-trimming; hence the flame attacked the apartment generally with considerable rapidity, and a wind blowing at the time caused the fire to spread through the vessel so very quickly as to compel many of those composing the crew to jump overboard, and to render the rescue of the boys from burning or drowning a difficult matter. The occurrence of this accident was made the occasion, in some of the public papers, to decry petroleum oil as a dangerous illuminating agent, although it was proved that the particular oil used at the time when the firc occurred had so unusually high a flashing-point that the consequent inferiority of its burning quality had been made the subject of complaint. This low volatility of the oil has been occasionally regarded as one very important element of safety in reference to its employment in lamps, but the lecturer will presently have to refer to circumstances which do not substantiate this view. At any rate, however, although the heated oil which was spilled on to the floor from the lamp was in a condition favourable to immediate ignition by the burning wick, it is not at all likely that the fire would have extended almost at once with uncontrollable violence, especially in face of the excellent discipline and arrangements in case of fire which were shown to have existed in the Goliath, if the scrupulous cleanliress and care had been enforced which were essential in a room where lamp filling and trimming were regularly carried out, and where it was necessary to keep some supply of oil for current consumption. Instead of this, the floor, and probably therefore other parts of the room, appear to have been in a condition most favourable to the rapid propagation of the flame; moreover, the evidence as to proper care having been taken to keep the supply of oil required for current use in such a way as to guard against its being accidentally spilled, or to impress the boys employed upon the work with the great importance of care and cleanliness, was by no means satisfactory, and there can be little doubt that this catastrophe has to be classed among the numerous accidents of a readily avertible kind which have contributed to lead the public to form an exaggerated estimate of the dangerous character of petroleum oil as an illuminant.

The employment of liquid hydrocarbons as competitors with animal and vegetable oils in lamps for domestic use is of comparatively recent origin, although petroleum or mincral naphtha in its crude or native conditions was used at a very early date in Persia and in Japan, in lamps of primitive construction, while in Italy it was similarly employed about a century ago.

The application of the most volatile products of coal distilla. tion to illuminating purposes in a crude way appears to have originated, so far as Great Britain is concerned, with the working of a patent taken out by Lord Dundonald in $178 \mathrm{I}$, for the distillation of coal, not with a view to producing gas, but for the production of naphtha, brown or heavy oil, and tar.

In 1820 , at about the time when gas-lighting was being established in London, his successors sold coal-naphtha ir the metropolis for illuminating purposes; but the first really stccessfui introduction of naphtha as an illuminating agent was made by Mr. Astley shortly afterwards, through the agency of the socalled Founders' blast-lamp, which came into use for workshops and yards in factories, and of the naphtha lamp of Real Holliday, of Huddersfield, with which we are well acquainted to this day, as, although it never became a success for internal illumina tion of houses, it still continues in extensive use almost in its original form, by itinerant salesmen and showmen.

In the Founders' lamp a current of air, artificially established, was made to impinge upon the flame and thus to greatly assist the combustion of the crude heavy oil used in it.

In the Holliday naphtha lamp the spirit finds its way slowly rom the reservoir through a capillary tube to a small chamber placed at a lower level, which has a number of circumferential perforations, and is in fact at the same time the burner of the lamp and the vapour producer which furnishes the continuous supply of illuminant, the liquid supplied to the chamber being vaporised by the heat of the jets of flame which are fed by its production.

Between 1830 and $185^{\circ}$ the knowledge of the production not only of oils but also of paraffin by the distillation of coal or shale became considerably developed by Reichenbach, Christison, Mitscherlich, Kane, du Boisson, and others, and the practical success attained by the latter was soon eclipsed by that of Mr. James Young, who, after establishing oil distillation at Alfreton from the Derbyshire petroleum, began to distil oils from the Bathgate mineral in 1850, and soon developed this industry to a remarkable extent.

The first lamps for burning liquid hydrocarbon which competed for domestic use, in this country, with the superior kinds of lamps, introduced after 1835 , in which animal or vegetable oils were burned (solar lamps and moderator lamps), were the so-called camphine lamps (known as the Vesta and Paragon lamps) in which carefully rectified oil of turpentine was used. They gave a brilliant light, but soon acquired an evil reputation as being dangerous, and liable, upon the least provocation, especially if exposed to slight draitghts, to fill the air with adhesive soot-flakes.

After a time Messrs. George Miller and Co., of Glasgow (who held for a time the concession of the products manufactured by Mr. Young) tried with some amount of success to use the lighter products from the boghead mineral in the camphine lamp, but the chief aim of Mr. Young appears to have been to produce the heavier oil suitable for lubricating purposes, the light oil or naphtha meeting with an indifferent demand as a solvent, in competition with coal-tar naphtha, in the manufacture of indiarubber goods. He, however, himsclf used the mineral oil produced at Alfreton in Argand lamps in the earliest days of his operations; a small sale of the Bathgate oil took place about 1852-53 for use in Argand lamps, and the earliest description of lamp employed in Germany, where the utilisation of mineral oil as a domestic illuminant was first developed, appears to have been of the Argand type.

In 1853 a demand sprang up for the lighter paraffin oils in Germany. For three or four years previously a burning oil was distilled from schist or brown coal at Hamburg by a Frenchman named Noblée, who gave it the name of photogene. The existence in Glasgow of a considerable supply of the oils became known to a German agent, and after they had been exported from Glasgow to Hamburg for a considerable time it was found that the chief purchaser was Mr. C. H. Stobwasser, of Berlin, who appears to have originated the really successful employment of mineral oils in lamps for domestic use, and to have been the first to bring out the flat-wick burners for these oils. After a time Messrs. Young discovered the destination of their oil, and, having brought over a number of German lamps, for which a ready sale was found, commenced the lamp manufacture upon a large seale, and rapidly developed the trade in mineral (or paraffin) oil for burning purposes, which attained to great importance some time before the American petroleum oils entered the market. In I859 a firm in Edinburgh supplied Young's company with nearly a quarter of a million of burners for lamps, and it was not until 1859 that the foundation of the United States' petroleum industry was laid by Col. G. L. Drake, who first struck oil (in Pennsylvania) at a depth of $7 \mathrm{I}$ feet, obtaining at once a supply of 1000 gallons per day. The lamps first used in America were probably of German make, but it need hardly be said that the lamp manufacture was speedily developed to a gigantic extent in that country. Some of the earliest lamps for burning mineral oil in dwellings which were produced in Germany and in Scotland, possess considerable interest as ingenious devices for promoting the perfect and steady combustion of the oil, and as attempts to dispense with the necessity of the chimney for the production of a steady light. In one of these a small lamp was introduced into the base or stand of the lamp proper, and a tube passed from over this littlc lamp, through the oil reservoir into the burner, so as to supply the latter with heated air. In another, a small fan or blower, with simple clockwork attached, to keep it in rapid motion, is placcl in the stand, and supplies the flame with a rapid current of air. Among other workers at the perfection of mineral oil lamps was the late Dr. Angus Smith, who produced a double-wick lamp some years before the beautiful duplex-lamps were first manufactured by Messrs. 
Hinks. Some of the more recent American lamps exhibit decided improvements in the details of construction of the oil reservoirs, the wick-holders and elevato:s, the arrangement for extinguishing the lamps, \&c.

It does not come within the province of this discourse to deal with the marvellous development of the petroleum industry in America, where the region of Western Pennsylvania now furnishes about 70,000 barrels of oil per day, having up to January $\mathbf{r}$, 1884, yielded a total of 250,000 , 000 barrels. Nor would it be relevant to enter upon the equally interesting topic of the recent extraordinary progress of the same industry in the Caucasus, which is chiefly due to Messrs. Nobel Brothers, further than to refer to the fact that the Balsu petroleum lamp oil, which supplies the entire wants of Russia, and is gradually obtaining a footing in Germany, and even here, appears, notwithstanding its comparatively high specific gravity, to be adapted for use in mineral oil lamps of the ordinary construction. This secms to be partly owing to the comparatively small proportion of lamp oil that is extracted from the crude Baku petroleum, in consequence of which the variety of hydrocarbons composing that product of distillation which is used for illuminating purposes, presents a narrower range than is the case in the ordinary American petroleum oil of commerce. It has also been established by carcful observations which Beilstein has instituted, that some American oil which is specifically lighter than the Baku oil is not so readily carricd up to the flame as the latter, by the capillary action of the wick. Mr. Boverton Redwoor has carried out some instructive experiments, employing different kinds of wick as siphons, and measuring the quantity of different descriptions of oil drawn over in corresponding periods of time by the different wicks. These showed that the Baku kerosine was drawn over with decidedly greater rapidity than samples of American petroleum of ordinary quality, but that, on the other hand, a sample of American kerosine of the highest quality exhibited a corresponding superiority over the Baku oil experimented with. The nature and behaviour of the wick plays a most important part in determining the efficiency and also the safety of a mineral oil or petrolcum lamp, as will be presently pointed out.

Ever since paraffin or petroleum oils, which may be included under the general designation of mineral oils, first assumed importance as illuminating agents, accidents connected with their use have continued to claim prominence among those casualties of a domestic characler which tend to cast suspicion on the safety of the material dealt with, or of the method of employing it, under the ordinary conditions fulfilled by its careful use.

The employment as an illuminant of the most volatile portions of petroleum which are classed as spirit or naphtha, has been chiefly limited to the wickless Holliday lamp, in which a small continuous supply to a chamber heaterl by the lamp flame which surrounds it, furnishes the vapour which maintains that flame, and to the small so-called sponge lamps or benzoline lamps, of which the body is filled with fragments of sponge, and which is intender to be charged only with as much spirit as the sponge will hold thoroughly absorbed; the small flame at the top of the wick-tube being fed by the gradual abstraction of the liquid from the snaked sponge, by the wick of sponge or asbestos which fills the tube. An ingenious application of naphtha as an illuminant consists in filling a rescrvoir with sponge fragments kept soaked with the spirit, the vapour of which descends by its own gravity through a narrow tube at the base of the reservoir, and issues from a fish-tail burner under sufficient pressure to produce a steady flame for some time.

(To be continued.)

\section{SOCIETIES AND ACADEMIES LONDON}

Mathematical Society, March 12.-J. W. L. Glaisher, F.R.S., President, in the chair.-Messrs. Philip Magnus and R. Lachlan were elected Members -Mr. J. J. Walker, F.R.S., marle a sccond communication on a method in the analysis of plane curves. - Mrs. Bryant, D.Sc., read a paper on the geometrical form of perfectly regular cell-structure. "Investigation of the properties of the rhombic dodecahedron supplies the clue to the solution of two interesting questions, which are the essential, because the pure geometrical, constituent of several questions as to actual furms in physical nature, such as the goometrical structure of compact tissues on the one hand, and the geometrical form of the honeycomb cells on the other hand. The first question is as follows:-If space were filled with spheres, and this spaceful of spheres were then crushed together symmetrically till the whole became a solid mass, what shape would each sphcre ultimately assume? Since twelve is the number of spheres that can be placed round one sphere, in contact with it and with one another, it is evident that each of these ultimate solids would be dodecahedral in shape. The second question is the counterpart of the first:-If space were filled with a homogeneous solid, in which equally efficient centres of excavation were distributed uniformly, what would be the ultimate form of the cells excavated, it being supposed that when the excavators cease their work the walls of the cells are uniform in thickness? The answer to the first question is manifestly the answer to this second question also." After a geometrical discussion the author says :-" We should expect to find this dodecahedral shape in nature wherever originally spherical cells have been uniformly pressed together in a complete manner. The condition is probably seldom fulfilled, and examples are therefore difficult to find. We may look for their fulfilment, however, in the centre of a mass of soap-bubbles." The paper then considers the casc of the honeycomb cells, with the conclusion: "The above cxplanation tends, however, to show that the bees need not be credited with any economical instinct to account for their work, but only with those simpler instincts, which enable them to carry out a joint work with perfect regularity and exactness, which simpler instincts, while sufficiently remarkable, are fairly within the limits of credibility."-Mrs. Bryant illustrated her remarks with several models of the cube and the rhombic dodecahedron.-Mr. Kempe, F.R.S., and the President (who stated that he had some few years since considered the matter from another point of view) made some interesting remarks in connection with the subject.--Prof. Sylvester, F.R.S., gave an account of a paper on the constant quadratic function of the inverse co-ordinates of $n+I$ points in space of $n$ dimensions; and Prof, Cayley, F.R.S., and Prof. Hart spoke on the same subject. As the hour was late Mr. Tucker (hon. sec.) merely communicated the titles of papers by Prof. K. Pearson (on the flexure of beams); Rev. T. C. Simmons (two elementary proofs of the contact of the "N.P." circle of a plane triangle with the inscribed and ascribed circles, together with a property of the common tangents); and by himself (two other proofs of the first part of Mr. Simmons's communication).

Linnean Society, March 5.-Sir J. Lubbock, Barl., President, in the chair.-Messrs. Jas. Epps, Jas. Groves and Wm, Ransom were clected Fellows of the Society. -Mr. E. M. Holmes ex* hibited a number of new species of British algæe, viz. thirteen from the south coast of England, and six obtained from Berwick-onTweed and Fifeshire. He also called attention to examples of the leaves of Eucalyphus Staigeriana, which are remarkable for their fragrant odour, resembling that of verbena, due to a volatile oil which is stated by Mr. Bailey, the Government botanist at Brisbane, to be likely to forin an article of commerce in the future. Mr. Holmes also showed a set of plant labels made from the leaves of the Talifat palm. Mr. W. Brockbank exhibited a specimen of Leucojim carpathicum, a variety of $L$. vernum, differing from the type by having the flowers tipped with yellow instead of green. The L. carpathicum is said now to be scldom met with in English nurseries. - Mr. C. B. Plowright showed and made remarks on a Ranunculus infected with spores of Urocystis pompholgodes. - Mr. E. Wethered exhibited some microscopic sections of the "Better Bed" coal-seam of Yorkshire and of the "Splint" coal from Whitehill Colliery, near Edinburgh. ITe mentioned that Prof. Huxley had drawn attention to the former as containing in quantity sporangia and spores of plants allicd to the recent club mosses. Mr. Wethered averred that these were only found in numbers in the topmost three inches of the coal-bed, but very sparsely in the lower portion of the seam. In the Edinburgh splint coal only four inches of the basal and but a part of the upper layer contained spores. Macrospores and microspores were present in both the coals, and, judging from these, he regarded them as belonging to plants resembling or allied to the recent genera Selaginella or Isoëtes. Mr. W. Carruthers replied, and dissented from this view.-Dr. F. Day read a paper on the rearing, growth, and breeding of salmon in fresh water in Great Britain. He referred to the statements and opinions of the older authorities, and then dwelt more at length on the more recent experiments of Sir James Maitland at Howietoun. In December, x 880, Sir James 